Article

\title{
Not One World but Two. The Future in Jewish Apocalyptic Literature
}

\author{
John Collins \\ Yale Divinity School, Yale University, New Haven, CT 06520, USA; john.j.collins@yale.edu
}

Received: 20 February 2019; Accepted: 25 March 2019; Published: 28 March 2019

\begin{abstract}
The Jewish apocalyptic literature that first appears in the Hellenistic period and continues into the Common Era developed a radically novel view of the future. As formulated in the apocalypse of 4 Ezra about the end of the first century CE, the Most High created not one world but two. This world must be utterly destroyed and replaced by a new creation. This view of the future is inherited in the New Testament, most strikingly in the Book of Revelation. It would have enormous but ambivalent implications for western history. On the one hand, it threatened to undermine the importance of working for a better life in this world. On the other hand, it offered hope to those who would otherwise have no hope at all.
\end{abstract}

Keywords: apocalyptic; death; eschatology; resurrection; Enoch; Flood; messiah; end of the world; millennium

The biblical tradition has long been celebrated for its linear view of history in contrast to the supposedly circular views of history that dominated the ancient Near East. (Dentan 1955). Perceptions of the common Near Eastern view were formed largely on the basis of the great creation myths such as the Babylonian Enuma Elish and the Ugaritic Baal Cycle, which posited a conflict between a god of life and fertility (Marduk, Baal) against forces of chaos and death (Tiamat, Mot, Yamm), which was re-enacted yearly in the cult. Despite the recurring drama, these myths posit a stable world order, which requires maintenance but does not allow for progress. In contrast, the most fundamental biblical story recounts movement towards a goal, from slavery in Egypt to the Promised Land. It is now widely recognized that this contrast is overdrawn. Israel and Judah also had their myths of kingship, which sought the maintenance of a stable order, and even the Exodus seems to have functioned as a founding myth in northern Israel, on the assumption that the goal of history had been reached. Nonetheless it is true that the biblical tradition as a whole is more future oriented than the other traditions that have come down to us from the ancient Near East.

\section{A New Exodus}

The reasons for that orientation are rooted in the history of Israel and Judah, and their successive destruction by the Assyrians and Babylonians. Already in the eighth century BCE the prophet Hosea portrayed the Assyrian invasions as divine punishment. He argued that the liberation from Egypt and the gift of the promised land were conditional on maintaining a covenantal relationship with Israel's God, and not worshipping other deities. The primary cause of their misfortunes, in his view, was the continued worship of Baal. The destruction wrought by the Assyrians in effect reduced Israel to a desert, thereby reversing Israel's history, taking the people back to the state they were in before they entered the promised land. So, he declares, "They shall return to the land of Egypt, and Assyria shall be their king" (Hos 11:5). But he also held out the prospect of a new Exodus:

Therefore, I will now allure her and bring her into the wilderness and speak tenderly to her; there she shall respond as in the days of her youth as at the time when she came out of the land of Egypt. (Hos 2:15) 
In historical reality, there would be no new Exodus for the northern kingdom of Israel. It would never be restored. The elite of the people were exiled to Assyria, and became the lost tribes of Israel. The motif of a new Exodus, however, would find new resonance two hundred years later, when the southern kingdom of Judah was destroyed by the Babylonians. In this case, the Babylonians were overthrown in turn by Cyrus of Persia, who permitted Jewish exiles to return to Jerusalem. An anonymous prophet, whose oracles were appended to those of Isaiah of Jerusalem, celebrated the edict of Cyrus with euphoria that still resonates in the music of Handel's messiah:

A voice cries out:

'In the wilderness prepare the way of the Lord,

Make straight in the desert a highway for our God.

Every valley shall be lifted up,

And every mountain and hill will be made low;

The uneven ground shall become level,

And the rough places a plain.

Then the glory of the Lord shall be revealed,

And all people shall see it together,

For the mouth of the Lord has spoken.' (Isa 40:3-5; Anderson 1962).

The new Exodus or new beginning is essentially a return to an idealized version of the former state: a world where people would sit under their own vines or fig trees, with no one to make them afraid (Micah 4:4). The vision of the future is this-worldly: the hope is to see one's children and one's children's children, and to be gathered to one's ancestors after a full and satisfying life.

The this-worldly character of hope in the Hebrew Bible is vividly illustrated in Isaiah 65, in a passage that dates from the period after the return from the Babylonian Exile. We know from many sources that this was a time of hardship. (See e.g., Haggai 1:5-6). Judah was small and poor, and had not recovered from the destruction wrought by the Babylonians. The prophet of Isaiah 65 seems to have been the spokesman for a group that felt marginal and oppressed even within Judah. (Hanson 1975). But things were about to change. In an oracle that is apparently addressed to the leaders of the community, he says: "my servants shall eat, but you shall be hungry; my servants shall drink, but you shall be thirsty, my servants shall rejoice but you shall be put to shame" (Isa 65:13). He continues:

For I am about to create new heavens and a new earth ...

I will rejoice in Jerusalem, and delight in my people;

No more shall the sound of weeping be heard in it,

Or the cry of distress.

No more shall there be in it

An infant that lives but a few days,

Or an old person who does not live out a lifetime

For one who dies at a hundred years will be considered a youth

And one who falls short of a hundred will be considered accursed.

They shall build houses and inhabit them;

They shall plant vineyards and eat their fruit.

They shall not build and another inhabit;

They shall not plant and another eat;

For like the days of a tree shall my people be. (Isa 65:17-22)

He ends with a flourish:

The wolf and the lamb shall feed together,

The lion shall eat straw like the ox; but the serpent-its food shall be dust!

They shall not hurt or destroy on all my holy mountain. (Isa 65:25) 
Despite the subversion of animal nature in the last verse, the striking thing about this passage is the degree to which the new creation resembles the old. This will be a world where people will still build houses and plant vineyards, and where people will still die, even if they live very long lives. The vision of human destiny that informed the books of Moses and the pre-exilic prophets has not been substantially changed, despite the language of a new creation.

\section{An End of Death?}

That vision of human destiny would change radically, however, in later postexilic Judaism, especially in the Hellenistic period. Many scholars think the change is adumbrated in some strands of post-exilic prophecy (Cook 2014). Some other chapters in the Book of Isaiah are especially significant in this regard. These are chapters 24-27, often dubbed "the Apocalypse of Isaiah," although they are in the form of prophetic oracles rather than apocalyptic visions. The date and authorship of these chapters is uncertain. Most scholars agree that they cannot be the work of the eighth century Isaiah of Jerusalem, but come from some time in the Persian period, probably from the fifth century (Collins 2015). They are remarkable in the biblical corpus for their vision of cosmic destruction:

For the windows of heaven are opened,

And the foundations of the earth tremble.

The earth is utterly broken,

The earth is torn asunder,

The earth is violently shaken.

The destruction, apparently, is not quite universal. The Lord of hosts will reign on Mt. Zion and in Jerusalem (24:23), which are presumably still intact. Mt. Zion here becomes a mythical holy mountain, where God comes to dwell among people. The future on Mt. Zion is not especially spiritual, certainly not ascetic:

On this mountain, the Lord of hosts will make for all peoples

A feast of rich food, a feast of well-aged wines,

Of rich food filled with marrow, of well-aged wines strained clear. (24:6)

But there will be a radical change. God, we are told,

Will destroy on this mountain

The shroud that is cast over all peoples,

The sheet that is spread over all nations;

He will swallow up death forever. (24:7-8)

The prophet here is playing on the old Canaanite myth, in which Mot, or Death, swallows up Baal for a time, until the god is rescued by his sister Anath. Isaiah 25 does not necessarily imply a retrospective resurrection of the dead, but rather a world where death and human suffering will be no more. Some scholars find a reference to individual resurrection in the following chapter, where the prophet says: "your dead shall live, their corpses shall arise. O dwellers in the dust awake and sing for joy? For ... the earth will give birth to those long dead." (Isa 26:19; see Roberts 2015, pp. 332-33). Most probably, however, the prophet is speaking of the restoration of the people of Judah from the death of the Babylonian Exile, as Ezekiel did in his famous vision of a valley full of dry bones (Ezekiel 37). The belief in individual resurrection would not emerge in Judaism for another three hundred years. When it did emerge, in the apocalyptic literature of the second century BCE, it engendered a profound shift in the understanding of the meaning and purpose of life that would dominate western consciousness for two millennia.

\section{Individual Resurrection}

There is only one undisputed reference to individual resurrection in the Hebrew Bible. It occurs in the last chapter of the latest book in the Hebrew canon, the Book of Daniel, which is classified 
as prophecy in Greek and Christian Bibles but is placed among the Writings in the Hebrew Bible (Collins 1993, pp. 390-98). The visions of Daniel, in chapters 7-12, refer quite clearly to the persecution of the people of Judea by the Syrian king Antiochus Epiphanes in the years 168-164 BCE, which gave rise to the Maccabean revolt. The clearest references are found in chapter 11, where the angel Gabriel gives Daniel a long account of Hellenistic history, in the guise of prophecy. (The revelation is supposed to have occurred in the third year of King Cyrus of Persia, or 536 BCE). No names are mentioned. The Ptolemies of Egypt are called "kings of the south," and the Seleucids of Syria are called "kings of the north." Antiochus Epiphanes is introduced in 11:21 as "a contemptible person on whom royal majesty had not been conferred." The account goes on to describe Epiphanes' two invasions of Egypt, and his humiliation by the Romans, called the Kittim (a name derived from Citium in Cyprus and applied variously to Greeks and Romans), during the second invasion. Then, we are told, he turned his attention to Jerusalem, and suppressed the traditional temple cult. Those who resisted his actions "shall fall by sword and flame, and suffer captivity and plunder." (Dan 11:33). Daniel is not referring here to the Maccabees, who are dismissed as "little help," but to people called "the wise," who try to give understanding to the common people.

Down to this point, the angelic account corresponds to what we know from other sources, including the books of Maccabees. The angel goes on to prophesy that the king, Antiochus, would die in the land of Israel, "between the sea and the holy mountain." This did not happen. Already in antiquity the philosopher Porphyry drew the obvious conclusion. The accurate "prophecy" was composed after the fact. The whole account was composed before the death of the king, which occurred in Persia in late 164 BCE. (Collins 1993, p. 25).

The death of the king was not, however, the climax of the revelation to Daniel. That revelation continues in chapter 12, with the claim that the archangel Michael would arise in victory:

At that time your people shall be delivered, everyone who is found written in the book.

Many of those who sleep in the land of dust shall awake, some to everlasting life, and some to shame and everlasting contempt. Those who are wise shall shine like the brightness of the sky and those who lead many to righteousness, like the stars forever and ever.

This is the only undisputed reference to individual resurrection in the Hebrew Bible. It is noteworthy in several respects. First, it does not promise universal resurrection. Only the very good and very bad will be raised for reward and punishment. Second, "the land of dust" from which they are raised is most probably Sheol, or the Netherworld, rather than the grave. Third, the resurrected dead are not said to come back on earth. Only the destination of the wise is specified: they will be like the stars. The meaning of the astral symbolism is clarified in another early apocalyptic writing, the Epistle of Enoch (1 Enoch 104:2-6). It means that the "wise" will be elevated to join the angels in heaven.

This is not all the Book of Daniel says about the future. It also affirms a hope that sovereignty under the whole heaven will be given to the Jewish people (Dan 7:27). Daniel does not predict that this world will come to an end; the "end" he expects is the end of the persecution and of the profanation of the temple. Life would then presumably continue on earth in the kingdom given to the people. The novelty of Daniel's hope, however, and the aspect that would have the most far-reaching consequences, was the hope for the elevation of the righteous to angelic status after death.

This hope had very clear implications in the context of the persecution described in Daniel 11 and in the books of Maccabees. (Collins 1997b). The traditional Jewish hope was that those who were faithful to the covenant would be rewarded with a long and peaceful life. In the Maccabean era, however, those who were faithful to the covenant could be punished by death. There was, then, a situation of cognitive dissonance; a discrepancy between was actually was the case and what was supposed to be. The belief in resurrection relieved the dissonance. People could afford to lose their lives in this world if they were assured of reward and exaltation in the hereafter. Thus was born the ideology of martyrdom and a new otherworldly vision of the goal of life. 


\section{Enoch}

The belief in reward and punishment after death, however, was not invented to address the persecution under Antiochus Epiphanes. We find it already in the books of Enoch, some of which are older than Daniel and may date from the third century BCE. (Nickelsburg 2001, pp. 7-8; Collins 2016, pp. 53-106). The figure of Enoch appears only briefly in the Book of Genesis, where we are told that he "walked with Elohim" (God or angels) and that God "took him" (Gen 5:22-24). These elliptic references gave rise to the legend that he associated with angels during his life time and made a round-trip to heaven, so he was uniquely qualified to reveal heavenly mysteries to humanity. At the end of his life, he did not go to the Netherworld like most human beings, but was taken up to God.

In the Book of the Watchers (1 Enoch 1-36), the story of Enoch is introduced as a counterpart to that of the Fallen Angels or Watchers. The Watchers, again, are extrapolated from a brief and elliptic passage in Genesis, which tells how the sons of God saw that the daughters of men were fair, and came down and took them as wives. In Genesis this action is not condemned as sinful, although it is not approved either. The main consequence is that God now limited the length of human lives, as a way of maintaining the boundary between divinity and humanity. Immediately after this comes the notice that human iniquity was so great that God decided to send the Flood, to wipe out humanity and start over with Noah. The biblical text does not make a causal connections between the descent of the "sons of God" and the spread of sinfulness, but it is not difficult to see how the connection could be made.

In the Book of the Watchers, the sons of God are called Watchers (a class of heavenly being). Their descent and mingling with human women is said to be a great sin. The sin of the Watchers does not lie only in sexual transgression. They also teach humanity many things that were previously unknown. These include sorcery and charms, but also metal working and the art of making weapons and jewelry, and various kinds of astronomical and astrological knowledge. In some other cultural contexts, even some Jewish contexts, the Watchers might have been hailed as culture bringers, founders of civilization. Here they viewed entirely negatively. Their teachings result in violence, through the use of weapons, fornication, through the use of jewelry, and impiety through astrology and sorcery. So we are told, there was much godlessness on the earth and the ways of humanity were made desolate.

This story provides the backdrop for the introduction of Enoch. Since Enoch is a scribe, the Watchers ask him to write out a petition for them and to deliver it to God. He writes it out, and recites it by the waters of Dan until he falls asleep. Then he has a vision, in which the clouds carry him up to heaven and into the presence of God. The petition is not accepted, but Enoch is given a message to take back to the Watchers. He is told to tell them:

"You should petition in behalf of humans, and not humans in behalf of you.

Why have you forsaken the high heaven, the eternal sanctuary,

And lain with women, and defiled yourselves with the daughters of men,

And taken for yourselves wives, and done as the sons of earth,

and begotten for yourselves sons, giants?

You were holy ones and spirits, living forever.

With the blood of women you have defiled yourselves,

And with the blood of flesh you have lusted,

And you have done as they do-flesh and blood, who die and perish.

Therefore I gave them women, that they might cast seed into them,

And thus beget children by them, that nothing fail them on earth.

But you originally existed as spirits, living forever,

And not dying for all the generations of eternity;

Therefore I did not make women among you."

The spirits of heaven, in heaven is their dwelling. (1 Enoch 15:2-7) 
The ideal, then, at least for angels, is to live a pure spiritual life, undefiled by fleshly contact and immune to death. The Watchers had foolishly abandoned this life. Enoch, in contrast, is a righteous human being who aspires to the heavenly, angelic, life and ultimately attains it.

Like Daniel, the Enoch literature also expresses some hope for this world. In the Book of the Watchers, the Flood is meant to cleanse the earth, after which it will be tilled and planted in righteousness (11:18). But this, of course, relates to the Flood in primeval times, after which the earth manifestly was restored. It is less clear how far the Enoch literature was concerned with the future transformation of the world. Much of it, especially the Epistle, rails against the rich and the mighty. The Apocalypse of Weeks promises the righteous that they will acquire possessions in righteousness, and the temple will be built in glory in the eighth week (1 Enoch 91:13). This would seem to imply a concern for the future of this world, but then in the tenth week the first heaven will pass away, and a new heaven will appear. In the Epistle of Enoch the hope of the righteous is that they will shine like the luminaries and become companions to the host of heaven.

\section{Two Traditions}

There were in fact two traditions about future hope that persisted in Jewish literature in the Hellenistic period and later (Mowinckel 1954, p. 281). One tradition, which we have seen already in the prophecy of the exilic and restoration periods, was focused on the restoration of Israel, and the attendant transformation of this world. The other, developed in the apocalyptic writings, looked for the destruction of this world and for salvation after death, whether this took the form of individual afterlife or of a general resurrection. These traditions had different origins and were in tension with each other, but nonetheless they were often maintained side by side.

Our main witnesses to the beliefs and hopes of Jews around the turn of the era are found in the Dead Sea Scrolls. The Scrolls preserve the writings of a sect, usually and plausibly thought to be the Essenes, but they also preserve a broader sampling of Jewish writings of the time (Collins 2010b). On the one hand, the Scrolls show that there was a revival of messianic expectation in the first century BCE (Collins 2010a. This is also attested in the Psalms of Solomon, which are often thought to be Pharisaic). "Messiah" literally means "anointed one. The term was applied to the king in the pre-exilic period but also to the High Priest. It acquired a new connotation in the postexilic period when there was no longer a native king in Jerusalem. Then the term "messiah" came to refer to a figure who would restore the native kingship, or the Davidic line, in accordance with Nathan's oracle to David in 2 Samuel 7, which had promised that there would always be a king from that line on the throne in Jerusalem. The hope for the restoration of the monarchy is found in prophetic books from the exilic and early postexilic periods, but it had apparently died out, or faded into the background, by the early Hellenistic period. There is no expectation of a messianic king in the apocalypses of Daniel and Enoch from the Maccabean period.

Messianic expectation, however, is prominent in the Dead Sea Scrolls, most of which date from the mid to late first century BCE. Two factors contributed to the resurgence. One was the fact that the Hasmoneans, the descendants of the Maccabees had set themselves up as kings in Jerusalem, even though they were not descendants of David. The Psalms of Solomon are especially scathing on this point. The Hasmoneans were those to whom God had made no promise, and had laid waste the throne of David. The conquest of Jerusalem by the Roman general Pompey was seen as divine punishment. So the Psalms pray that God would raise up a legitimate Davidic king. But the Roman conquest soon became the second factor. The Romans were foreigners, and Pompey had profaned the temple. So the Psalms went on to pray for a messianic king who would purify Jerusalem from gentile defilement (Psalms of Solomon 17; Collins 2010a, pp. 54-60).

The Scrolls distinctively speak of two messiahs, one of Aaron and one of Israel. These would be the leaders of Israel in "the end of days," the period at the end of history which the sectarians thought had already begun. There was biblical precedent for referring to the High Priest as well as the king as "messiah." The fact that the sectarian texts speak of both reflects their hopes for the future of Israel. 
The messiah of Israel was the kingly figure who would drive out the Romans. He would also need to prevail over Jews who did not abide by the sectarian interpretation of the law, especially in matters of purity. (Both the Romans and Jewish adversaries are probably included in the Sons of Darkness who would be defeated in a final war, in which the archangel Michael would take the lead but the messiah would also play a role). The messiah of Aaron would be the High Priest of restored Jerusalem. It is clear then that the sectarians hoped for the restoration of a proper cultic system, and a situation where the whole people would accept the strict sectarian interpretation of the Jewish Law.

But the Scrolls also attest to a different kind of expectation. They are not greatly concerned with an end of this world. The only passage that can be taken as referring to the end of the physical world is a poetic passage, $1 \mathrm{QH}^{\mathrm{a}}$ col. 11 , in a hymn, and is not necessarily to be taken literally. But they speak regularly of the members of the community mingling with the angels (Dimant 2014). While the apocalypses of Enoch and Daniel had envisioned fellowship with the angels after death, the sectarians apparently believed that they were already mingling with the heavenly host in this life. Consequently, they attach no significance to death, and seldom speak of resurrection (Collins 1997a, pp. 110-29). This feature of the Scrolls helps explain a controversial aspect of the Essene sect. The Greek and Roman accounts of the Essenes all emphasize that they were celibate, although the Jewish historian Josephus allows that some of them married. Many scholars have been reluctant to believe that a Jewish community would adopt a celibate life-style, since, according to Genesis, God had commanded humanity to increase and multiply and fill the earth (Gen 1:28). But as we have seen in 1 Enoch, some Jews in the Hellenistic period came to believe that the goal of life was not to procreate but to become like the angels, who did not need sexual relations because they were spiritual and would live forever. The sectarians of the Scrolls likewise aspired to an angelic life, and so it is entirely credible that some of them would have adopted a celibate life-style. Their angelic aspirations also shed light on their detachment from worldly goods, which were essentially irrelevant to the angelic holiness to which they aspired.

\section{Fourth Ezra}

By the end of the first century of the common era, we find attempts to combine different traditions in an eschatological sequence (Collins 2016, pp. 240-80). The fullest example of this tendency is found in 4 Ezra (=2 Esdras 3-14), written in the aftermath of the destruction of Jerusalem at the end of the first century CE. (Stone 1990). The traditional messianic age will come first, and will last for four hundred years. But then "the messiah will die, and all who draw human breath. And the world shall be turned back to primeval silence for seven days, as it was at the first beginning" (4 Ezra 7:29-30). After seven days, the world is roused and the dead come back to life. Then the Most High appears on the seat of judgment, "and compassion shall pass away, and patience shall be withdrawn and only judgment shall remain." (7:33-34). All who have denied the Most High are condemned to the pit of torment. Ezra complains that only a few will be saved, and is told that whatever is precious is always rare. The Most High has made not one world but two (7:50), and the present world is not the end (7:112). Ultimately, salvation is not to be found in this world but in the world to come. In 4 Ezra, the second world is presented in temporal rather than spatial terms.

A very similar view of the future can be found in the Book of Revelation (Frey 2012). At the climax of the book, in chapter 19, Christ comes from heaven on a white horse to strike down the nations. Satan is bound in a pit for a thousand years. Those who had been faithful to Christ, at the cost of their lives, come to life and reign with him for a thousand years (Rev 20:4). When the thousand years are ended, Satan is released, and there is a final battle, followed by the general resurrection of the dead, who are judged according to their works. In Revelation 21, a new Jerusalem comes down from heaven.

Both 4 Ezra and Revelation posit a period of fulfillment on earth, the messianic reign of 400 years in 4 Ezra and the millennium in Revelation, but this period of fulfillment is not the ultimate goal of history. That goal lies in another world beyond this one, a new creation after this world has been 
destroyed. This view of history has persisted through western history, and is has been more influential in Christianity than in Judaism.

\section{Hope or Despair?}

In American Protestant tradition, two traditions can be distinguished by the way they map human history onto the Book of Revelation (Boyer 1992, and more broadly Stein 1998, pp. 36-178). "Post-millennialists" believe that the Second Coming of Christ comes after the millennium. Before that, the millennium is a time of peace and prosperity, when his followers spread the Gospel on earth. This was for long the dominant belief among American Protestants, including such notable figures as Jonathan Edwards (1703-58). Postmillennial eschatology generally implied an optimistic view of history. Those who held this view traditionally worked to bring about the millennium on earth and were supportive of social causes such as the abolition of slavery (Balmer 2016).

Premillennialism in contrast, holds that the Second Coming must take place before the inauguration of the millennium. This implies a more pessimistic view of history. The millennium can only come after a period of trials and tribulations, and the utter destruction of the earth. This understanding of the end-time was popularized in North America by the Dispensationalist movement associated with John Nelson Darby, an Anglo-Irish minister, who became the leader of the Plymouth Brethern. According to Darby's system, pieced together from the Books of Daniel and Revelation, the last phase of history would begin with the Rapture, as described in 1 Thessalonians. This would be followed by the reign of the Antichrist, or the Tribulation. The latter part of the Tribulation would be almost unbearable, but it would culminate in the battle of Armageddon and the triumph of Christ over Satan. Only then would the millennium follow (Boyer 1992, p. 88).

In this view of eschatology, there was much less room for human initiative, and much less reason to work to improve conditions on earth. Pre-millennialist theologians have traditionally had little time for social engineering. Cyrus Scofield, author of the best-selling Scofield Reference Bible, declared: "the true mission of the church is not the reformation of society. What Christ did not do, the Apostles did not do. Not one of them was a reformer" (Boyer 1992, p. 298). An eminent evangelical theologian, John Walvoord, assured his readers that "it is not God's purpose in the present age to have social justice or to have all the ills and problems of life removed now." (Walvoord 1971). The Christian task was to save souls from the coming Wrath. The attitudes inspired by Pre-millenialist theology have proven especially controversial in matters relating to ecology, since this world is written down for destruction. "Hellfire is the real global warming," as one evangelical preacher put it (Grove 2008).

The ancient writers who composed the Jewish and early Christian apocalypses had no concept of global warming or ecological disasters of the type that threaten the modern world. They surely were concerned with justice in this world. They typically complain bitterly about social and political oppression. The Epistle of Enoch berates the wealthy:

Woe to you who acquire gold and silver unjustly and say,

'we have become very wealthy,

And we have gotten possessions,

And we have acquired all that we have wished.

And now let us do what we have wished,

For silver we have treasured up in our treasuries

And many goods in our houses, and as water they are poured out.'

You err! For your wealth will not remain, but will quickly ascend from you;

For you have acquired everything unjustly,

and you will be delivered to a great curse. (1 Enoch 97:7-10)

The Book of Revelation denounces Rome as the whore of Babylon and calls on God to repay her for what she has done: 
Render to her as she herself has rendered

And repay her double for her deeds...

As she glorified herself and lived luxuriously,

So give her a like measure of torment and grief. (Rev 18:6-9; Yarbro Collins 1980)

As Steven Friesen has argued: “John's robust critique of Rome included what we would call economy, politics, trade, religion, popular opinion, and ethics, making his opposition to imperial power systematic enough to be seen as opposed to any empire." (Friesen 2014, p. 169; compare Yarbro Collins 2011).

Revelation may be the most colorful protest against imperial injustice in ancient literature, but it is not a lone voice. In 4 Ezra 11, the messianic lion confronts the Roman eagle:

Are you not the one that remains of the four beasts which I had made to reign in my world, so that the end of my times might come through them? You, the fourth that has come, have conquered all the beasts that have gone before; and you have held sway over the world with much terror, and over all the earth with grievous oppression; and for so long you have dwelt on the earth with deceit. And you have judged the earth, but not with truth, for you have afflicted the meek and injured the peacable, you have hated those that tell the truth, and have loved liars ... and so your insolence has come up before the Most High, and your pride to the Mighty One ... Therefore you will surely disappear ... so that the whole earth, freed from your violence may be refreshed and relieved." (4 Ezra 11:38-46)

Several apocalypses also express their concern over the pollution of this world, although they envision that pollution in spiritual rather than physical terms. For example, in the Book of the Watchers the angels implore the Lord to "cleanse the earth from all impurity and from all wrong" (1 Enoch 10:20) after the sin of the Watchers.

It is clear enough that the expectation of an end to this world, and hope for life beyond it, did not bespeak indifference to the welfare of this world on the part of the apocalyptic authors. If they hoped for its destruction, it was because this seemed to be the only way to bring an end to oppression. The expectation of cosmic destruction in Revelation by no means made the conduct of the Roman empire acceptable in the present. On the contrary, the visions of destruction are a cry of protest, as indeed the destructive actions of modern apocalyptists (such as the suicide bombers of 11 September 2001) are too.

Nonetheless, the apocalyptic vision of the future has severe limitations. It is all very well to rely on God to do what we cannot hope to accomplish by human means, but that reliance carries with it a risk of quietism. St. Paul, in the New Testament, could tell the Corinthians that it did not matter whether one was a slave, since the time had grown short and slave and free were equal before God (1 Cor 7:21-24). In the same spirit, he told his followers that everyone should be subject to the governing authorities (Rom 13:1). The later epistles ascribed to Paul, though probably not written by him, went farther in demanding subjection to social norms in the present. This was surely not the spirit of Revelation, nor of the Jewish apocalypses, but the reliance on divine intervention opened the door to quietistic acceptance of the status quo in the present. There is, in short, a risk, when people do not take responsibility for fashioning their own future.

The aspiration to a spiritual, angelic, life also has its problematic side. Those who have their treasure in heaven are detached from the things of this world, and less likely to be motivated by greed and lust, or to oppress others in pursuit of temporal gain. But conversely, they are less likely to resist oppression or to care about fashioning a just society on earth. Withdrawal to the spiritual world may be an effective way to cope with oppressive situations that one cannot change, but it is not conducive to improving conditions in this world. 
Of course, not all apocalyptic visionaries have been quietist. Some have taken it upon themselves to "force the end," and bring about utopia on earth (Cohn 1970; Juergensmeyer 2003). Such activism brings problems of its own. But perhaps the greatest contribution of the apocalyptic tradition to thought about the future is the insistence that the world as we know it will not always be so. By imagining an alternative world, however it is conceived, the visionaries held out the hope that the status quo is not inevitable, and that things might be otherwise. That conviction that the present order can be, and will be, changed is the foundation on which all hope for the future is based.

Funding: This research received no external funding.

Conflicts of Interest: The author declares no conflict of interest.

\section{References}

Anderson, Bernard W. 1962. Exodus Typology in Second Isaiah. In Israel's Prophetic Heritage: Essays in Honor of James Muilenburg. Edited by Bernard W. Anderson and Walter Harrelson. New York: Harper, pp. 177-95.

Balmer, Randall. 2016. Evangelicalism in America. Waco: Baylor.

Boyer, Paul. 1992. When Time Shall Be No More. Prophecy Belief in Modern American Culture. Cambridge: Harvard.

Cohn, Norman. 1970. The Pursuit of the Millennium. New York: Oxford University Press.

Collins, John J. 1993. Daniel. A Commentary on the Book of Daniel. Hermeneia. Minneapolis: Fortress.

Collins, John J. 1997a. Apocalypticism in the Dead Sea Scrolls. London: Routledge.

Collins, John J. 1997b. Apocalyptic Eschatology as the Transcendence of Death. In Seers, Sibyls, and Sages in Hellenistic-Roman Judaism. Journal for the Study of Judaism Supplements 54. Leiden: Brill, pp. 75-97.

Collins, John J. 2010a. The Scepter and the Star. Messianism in Light of the Dead Sea Scrolls, 2nd ed. Grand Rapids: Eerdmans.

Collins, John J. 2010b. Beyond the Qumran Community. The Sectarian Movement of the Dead Sea Scrolls. Grand Rapids: Eerdmans.

Collins, John J. 2015. The Beginning of the End of the World in the Hebrew Bible. In Apocalypse, Prophecy, and Pseudepigraphy. On Jewish Apocalyptic Literature. Grand Rapids: Eerdmans, pp. 34-53.

Collins, John J. 2016. The Apocalyptic Imagination, 3rd ed. Grand Rapids: Eerdmans.

Cook, Stephen L. 2014. Apocalyptic Prophecy. In The Oxford Handbook of Apocalyptic Literature. Edited by John J. Collins. New York: Oxford University Press, pp. 19-35.

Dentan, Robert C., ed. 1955. The Idea of History in the Ancient Near East. New Haven: Yale.

Dimant, Devorah. 2014. Men as Angels: The Self-Image of the Qumran Community. In History, Ideology and Bible Interpretation in the Dead Sea Scrolls. Tübingen: Mohr Siebeck, pp. 465-72.

Frey, Jörg. 2012. Was erwartet die Johannesapokalypse? Zur Eschatologie des letzten Buches der Bibel. In Die Johannesapokalypse. Kontexte-Konzepte-Rezeption. Edited by Jörg Frey, James A. Kelhoffer and Franz Tóth. Tübingen: Mohr Siebeck, pp. 473-551.

Friesen, Steven. 2014. Apocalypse and Empire. In The Oxford Handbook of Apocalyptic Literature. Edited by John J. Collins. New York: Oxford University Press, pp. 163-79.

Grove, Jim. 2008. Hellfire is the Real Global Warming. Available online: http://ydr.inyork.com/ci_11103726 (accessed on 25 March 2019).

Hanson, Paul D. 1975. The Dawn of Apocalyptic. The Historical and Sociological Roots of Jewish Apocalyptic Eschatology. Philadelphia: Fortress.

Juergensmeyer, Mark. 2003. Terror in the Mind of God. Berkeley: University of California.

Mowinckel, Sigmund. 1954. He That Cometh. Nashville: Abingdon Press.

Nickelsburg, George W. 2001. 1 Enoch 1. Hermeneia. Minneapolis: Fortress.

Roberts, Jimmy J. M. 2015. First Isaiah. Hermeneia. Minneapolis: Fortress.

Stein, Stephen J., ed. 1998. The Encyclopedia of Apocalypticism. Vol. 3. Apocalypticism in the Modern Period and the Contemporary Age. New York: Continuum.

Stone, Michael E. 1990. Fourth Ezra. A Commentary on the Book of Fourth Ezra. Hermeneia. Minneapolis: Fortress.

Walvoord, John F. 1971. Why Must Christ Return? In Prophecy and the Seventies. Edited by Charles Lee Feinberg. Chicago: Moody, p. 43. 
Yarbro Collins, Adela. 1980. Revelation 18: Taunt-Song or Dirge? In L'Apocalypse johannique et l'Apocalyptique dans le Nouveau Testament. Edited by Jan Lambrecht. Leuven: Leuven University Press, pp. 185-204.

Yarbro Collins, Adela. 2011. Portraits of Rulers in the Book of Revelation. In Neues Testament und hellenistisch-jüdische Alltagskultur. Wechselseitige Wahrnehmungen. III. Internationales Symposium zum Corpus Judaeo-Hellenisticum Novi Testamenti. Edited by Roland Deines, Jens Herzer and Karl-Wilhelm Niebuhr. Tübingen: Mohr Siebeck, pp. 275-99. 